\title{
The interplay of HIV and human papillomavirus-related cancers in sub- Saharan Africa: scoping review
}

\author{
Kabelo Matjie Bridget Lekoane ${ }^{1}$, Desmond Kuupiel ${ }^{1,2^{*}}$, Tivani P. Mashamba-Thompson ${ }^{1}$ and Themba G. Ginindza ${ }^{1}$
}

\begin{abstract}
Background: People living with HIV (PLHIV) are at a high risk of developing HPV-related cancers. HPV-related malignancies occur frequently and/or are high among PLHIV, with cervical cancer as a designated AIDS-defining condition. We aimed to explore the evidence on the interplay of HIV and HPV-related cancers in sub-Saharan Africa (SSA).

Methods: The scoping review was guided by Arksey and O'Malley's framework. We searched for literature from the following databases: PubMed; World Health Organization (WHO) Library; Science Direct; Google Scholar and EBSCOhost (Academic search complete, Health Source: Nursing/Academic Edition, CINAHL). Studies reporting on evidence HIV and HPV-related cancers interplay in SSA were eligible for inclusion in this review. The Mixed Methods Appraisal Tool (MMAT) tool was used to assess the risk of bias of the included studies. Preferred Reporting Items for Systematic Reviews and Meta-Analyses (PRISMA) was used for reporting the search results. Thematic analysis used to reveal the emerging themes from the included studies.
\end{abstract}

Results: A total of 74 potentially eligible articles were screened. Of these, nine ( 7 reviews, 1 transversal case controls, and 1 quantitative study) were eligible for data extraction. The studies reported about a total of 16,351 participants in different settings. The nine included studies showed evidence of cervical cancer among HIV-infected women and distribution of HPV infection and cervical abnormalities among HIV-positive individuals. In the four studies generalizing about HIV and anal cancer, only one reported about HPV. Two studies generally reported about HIV and head and neck cancers and one reported about interaction of HIV with vaginal cancer, vulvar cancer, and penile cancer, respectively.

Conclusion: HIV positivity is associated with increased prevalence of HPV infection on different anatomic sites, which will result in increased burden of HPV-related cancers among PLHIV. Furthermore, primary studies with robust study designs aimed at investigating the risk developing HPV-related cancers among PLHIV are recommended.

Systematic review registration: PROSPERO CRD42017062403

Keywords: HPV, HPV-related cancers, HIV, Sub-Saharan Africa

\footnotetext{
* Correspondence: desmondkuupiel98@hotmail.com

'Discipline of Public Health Medicine, School of Nursing and Public Health,

University of KwaZulu-Natal, Durban, South Africa

${ }^{2}$ Department of Public Health Medicine, School of Nursing and Public Health,

University of KwaZulu-Natal, Durban, South Africa
}

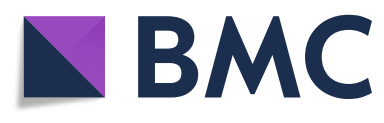

(c) The Author(s). 2020 Open Access This article is licensed under a Creative Commons Attribution 4.0 International License, which permits use, sharing, adaptation, distribution and reproduction in any medium or format, as long as you give appropriate credit to the original author(s) and the source, provide a link to the Creative Commons licence, and indicate if changes were made. The images or other third party material in this article are included in the article's Creative Commons licence, unless indicated otherwise in a credit line to the material. If material is not included in the article's Creative Commons licence and your intended use is not permitted by statutory regulation or exceeds the permitted use, you will need to obtain permission directly from the copyright holder. To view a copy of this licence, visit http://creativecommons.org/licenses/by/4.0/ The Creative Commons Public Domain Dedication waiver (http://creativecommons.org/publicdomain/zero/1.0/) applies to the data made available in this article, unless otherwise stated in a credit line to the data. 


\section{Background}

The International Agency for Research on Cancer (IARC) classified both human papillomavirus (HPV) and human immunodeficiency virus (HIV) type 1 as carcinogens [1], and studies demonstrated that HPV is a direct carcinogen and HIV-1 is an indirect carcinogen through immune suppression [1]. HPV infection is etiologically responsible for all cervical cancers, a subset of cancers of the anus, oropharynx, penis, vagina, and vulva [2, 3]. Individuals with HIV and acquired immunodeficiency syndrome (AIDS) are at a high risk of developing HPVrelated cancers [4-9]. Incidence of HPV-related diseases continued to rise as compared to the incidence of many HIV-associated comorbidities, which decreased in the era of antiretroviral therapy (ART) $[10,11]$. According to the United Nations Programme on AIDS (UNAIDS), in 2016, the clear majority of PLHIV were from lowand middle-income countries (LMIC) with 25.5 million located in SSA [12]. With the aging of the population of HIV-infected individuals due to combined antiretroviral therapy (cART), the landscape of malignancies has shifted. Classical AIDS-defining malignancies (ADM) have decreased; however, other non-AIDS-defining malignancies (NADMs) such as anal, lung, colorectal, and liver cancers continue to pose a significant health threat to patients with HIV $[13,14]$.

As evidenced by the HIV and AIDS Cancer Match Study, cervical cancer incidence among HIV-infected women in the USA has been unchanged since the introduction of ART at 64.2 cases per 100,000 person-years from 1990 to 1995 compared to 86.5 cases per 100,000 person-years from 1996 to 2002 [15]. From cohort studies it was reported that anal cancer rates appear to be increasing and the anal cancer incidence in men with HIV has climbed from 35 to 49 cases per 100,000 personyears in the pre-ART era to the range of 92 to 144 cases per 100,000 person-years $[16,17]$. The risk of cancer in HIV-infected individuals as compared to the general population increased as high as 29 times for anal cancer, 4 times for penile cancer, 6 times for vulvar and vaginal cancer as well as for cervical cancer [1].

The introduction of HPV vaccine in the immunization programs in high-income countries had played a key role in the reduction of the incidence of cervical cancer using either the quadrivalent (Gardasil) or the bivalent (Cervarix) HPV vaccine [18]. HPV Quadrivalent Gardasil vaccine was introduced, and it provides protection against persistent infection and disease associated with HPV types 6, 11, 16, and 18 for women with no evidence of prior HPV infection and became FDA-approved in 2006 [18]. Studies demonstrated that HPV vaccination prevented the infection of HPV types 16 and 18 infections and associated cervical epithelial neoplasm 2 or 3, adenocarcinoma in situ, or invasive cervical cancer with
$98 \%$ efficacy in young women without prior HPV 16 or 18 infections [18]. Efficacy in preventing the development of genital warts and vulvar, vaginal, and perianal HPV-related disease associated with the vaccine HPV types in women without prior infection with these HPV types were reported to be $100 \%$ [19]. Although there are limited treatment options for HPV-associated diseases in HIV-infected people, there are opportunities for disease prevention with vaccination. HPV-associated cancers in $\mathrm{HIV}$-infected persons persist irrespective of the apparent immune reconstitution with ART [20] and the importance of optimizing screening; prevention and treatment of these diseases become even more important.

Therefore, the aim of this study is to explore the evidence on the interplay of HIV and HPV-related cancers in SSA. It is anticipated that the study findings will help to strengthen the implementation of control and prevention policy and the planning of prevention strategies incorporating HPV infection prevention especially among the youth and HIV-infected people. Even though there is information about HPV vaccine and testing within cervical cancer screening programs, it has been shown that the patients' and public's knowledge on HPV-related cancers is still limited [21, 22]. Therefore, contributions of a scoping review gains importance and relevance by demonstrating the current evidence to identify research gaps and suggest novel ideas for future research.

\section{Methods \\ Study design}

This study is a part of the larger study entitled "Mapping evidence on the distribution of human papillomavirusrelated cancers in sub-Saharan Africa: scoping review protocol." This large study is registered in PROSPERO under registration number CRD42017062403. It is accessible via this link: https://www.crd.york.ac.uk/PROS$\mathrm{PERO} /$ display_record.asp?ID=CRD42017062403.

A comprehensive description of the methods used in this study can be found in the published protocol [23].

Scoping review was chosen as the best method to map the evidence on interplay of HIV and HPV-related cancers in SSA. Arksey and O'Malley's framework [24] incorporating the recommendations of Levac et al. [25] was employed to guide this scoping review study. The Arksey and O'Malley framework involves identifying the research question; identifying the relevant literature; identifying the study selection; charting the data; and collating, summarizing, and reporting the results. We searched for peer-reviewed quantitative studies reporting on the interplay of HIV and HPV-related cancers in SSA. We used Pluye et al.'s version 2011 tool to perform quality assessment of the included primary studies [26]. The results of this scoping review are presented according to the recommendations of Preferred Reporting 
Items for Systematic Reviews and Meta-Analyses (PRISMA) [27]. We applied the PEOs (population, exposure, outcome, and setting) framework for scoping reviews in determining the eligibility research question for a scoping review project.

\section{Search strategy}

We searched several online databases including PubMed, World Health Organization (WHO) Library, Science Direct, and Google Scholar, and within EBSCOhost platform, the following databases were searched: Academic Search Complete, Health Source: Nursing/Academic Edition, and CINAHL with full text for published studies. The search took place from April 2017 to July 2017. We used the following keywords on the search databases: HPV-related cancers, HIV, prevalence, incidence, and sub-Saharan Africa (to search titles of the eligible studies). Boolean terms AND/OR were used to separate the keywords during the search. There was no language and date restriction. Medical Subject Headings (MeSH) terms were included in the search. The literature search strategy in the databases was developed by KMBL in consultation with a librarian. Reference sections of included full articles were reviewed to identify additional eligible articles. Detailed description of the database search strategy is attached in Additional file 1: Table S1.

\section{Study selection}

Firstly, KMBL searched the eligible titles guided by the eligibility criteria from the databases and imported them to a new Endnotes X7 library created for this scoping review. Duplicates were removed before the start of the abstract screening phase. Both abstract and full article screening tool were developed in Google forms using the inclusion criteria. Secondly, two skilled reviewers (KMBL and DK) screened all retrieved abstracts against the eligibility criteria. To be selected for the next stage of the review, a study had to be conducted among humans and report of data on HIV and assessment of the interplay with HPV-related cancers are needed. If the reviewer was uncertain of the eligibility of the study population while the intervention, outcome, and study setting were eligible, the article was not excluded but rather carried onto the next stage of the selection process. Disagreement at this stage were resolved via discussions until a consensus was reached. Again, two independent reviewers (KMBL and $\mathrm{DK}$ ) did a full article screening and a third reviewer (TPM-T) was involved to resolve the disagreements. To measure the inter-rater agreement between reviewers, we used Cohen's kappa coefficient (к) statistic using Stata 13.0SE (StataCorp College Station, TX, USA).

\section{Eligibility criteria}

\section{Inclusion criteria}

This study included the following:

- Studies involving individuals of all ages

- Studies focused on HIV and HPV-related cancers

- Studies reporting evidence from SSA countries (Angola, Benin, Botswana, Burkina Faso, Burundi, Cameroon, Cape Verde, Central African Republic, Chad, Comoros, Congo (Brazzaville), Congo (Democratic Republic Côte d'Ivoire, Djibouti, Equatorial Guinea, Eritrea, Ethiopia, Gabon, The Gambia, Ghana, Guinea, Guinea-Bissau, Kenya, Lesotho, Liberia, Madagascar, Malawi, Mali, Mauritania, Mauritius, Mozambique, Namibia, Niger, Nigeria, Réunion, Rwanda, Sao Tome and Principe, Senegal Seychelles, Sierra Leone, Somalia, South Africa, Sudan, Swaziland, Tanzania, Togo, Uganda, Western Sahara, Zambia, Zimbabwe).

- Quantitative study designs

\section{Exclusion criteria}

This study excluded the following:

- Studies that do not focus on HPV-related cancers

- Studies that did not focus on HIV and HPV-related cancers

- Studies that reported about HIV only

- Studies that reported evidence from countries outside SSA

\section{Charting data}

We abstracted the data from the included studies using a piloted form designed in Google forms. The following information was extracted from included studies: author and date, study setting, intervention, age, percentage of males/females, gender, study aim, and study designs.

\section{Summary and collating}

Thematic analysis was performed to identify the interplay of HIV and HPV-related cancers in SSA from the included studies. The included manuscripts were manually coded into categories, which were grouped into the following five themes:

- Cervical cancer

- Anal cancer

- Vaginal and vulvar cancers

- Head and neck cancers

- Penile cancer 


\section{Quality of evidence}

The quality assessment of included studies was performed using Mixed Methods Appraisal Tool (MMAT)-Version 2011, with the purpose of evaluating the risk of bias [26]. Two reviewers (KMBL and DK) independently assessed the quality of the studies included and the results compared for accuracy and consistency, and TMP-T resolved the discrepancies. The risk of bias scale score for studies was based on the following domains: clarity of the research questions, confidence in the assessment of the research question, appropriateness of data sources collected; and suitability of statistical analysis to address the research question or objective. There are other domains included: clear description of the design and allocated concealment, complete outcome data and the withdrawal, recruitment of participants, appropriate measurements and comparable participants, relevant sample and representative of the population, relevant design and integration of the methods, and researcher's appropriate consideration of the method. An overall quality percentage score of the included studies was calculated, and the scores were interpreted as high quality (76-100\%), average quality (51 to $<76 \%$ ), and low quality $(\leq 50 \%)$.

\section{Results}

The initial search yielded a total of 25,835 articles from all databases. Applying our exclusion criteria, the number of studies reduced to 194 (Fig. 1). The abstract screening tool was used, and the eligible 194 articles were screened against the eligibility criteria, from those 74 which were included for full article screening. From the 74 studies screened at full article screening, 9 articles were deemed eligible for inclusion in data extraction. The inter-rater agreement at the full-text screening phase was $86.49 \%$ versus $64.57 \%$ expected by chance which constitutes moderate to substantial agreement (Kappa statistic $=0.62, p$ value $<0.05)$. In addition, McNemar's chi-square statistic suggests that there is not a statistically significant difference in the proportions of yes/no answers by the reviewer with a $p$ value $>0.05$ (Additional file 2: Table S1).

A total of 120 studies were excluded from this study as they did not meet the inclusion criteria for this study. Of those 74 studies that underwent full manuscript review, 65 of them were found to have no valuable data for analysis in this study. A total of 53 articles did not report anything about the study setting of interest which is SSA [1, 28-79], 7 did not report anything about HIV and HPV-related cancers [2, 41, 80-84], and 5 reported about HIV but not HPV-related cancers [85-89].

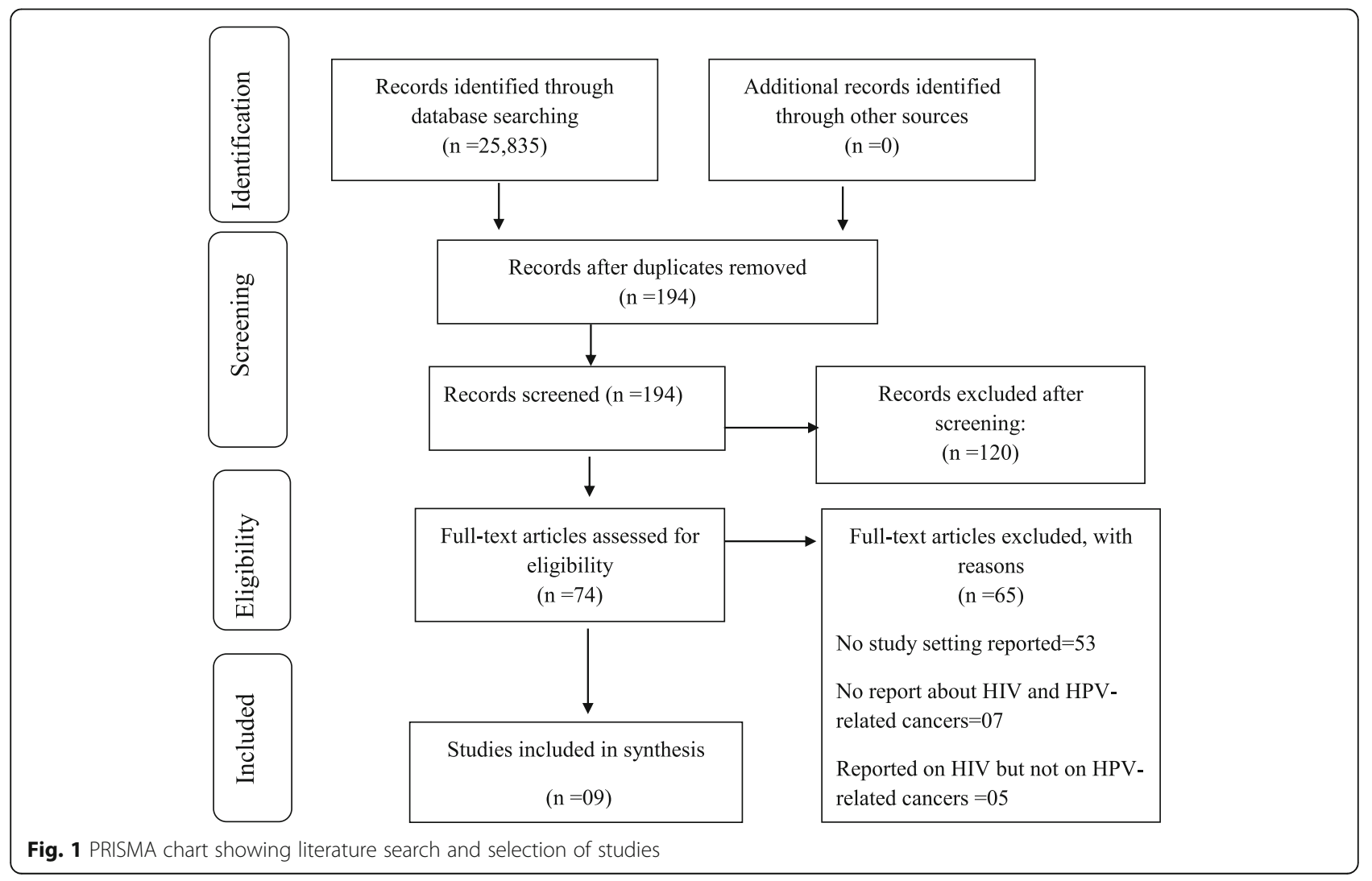




\section{Characteristics of the included studies}

The included studies comprise of review articles which made the bulk of the articles with $77.7 \%$ (7/9) [90-96] and (1/9) transversal case control study [97] and (1/9) quantitative study [98] and each contributed 11.1\% respectively.

The studies were done and reviewed from different study settings. About $11.1 \%$ (1/9) study generalized about SSA with no specific country mentioned [90], 44\% (4/9) reported about Uganda [91, 92, 95, 96], 33\% (3/9) South Africa (SA) [93, 95, 96], 22\% (2/9) Senegal [94, 96], (1/9) Zambia [93], (1/9) Nigeria [98], and (1/9) Benin [97], and each contributed $11 \%$ respectively. Among the included studies, only three were conducted in an urban setting; those of the rest of the studies were not mentioned. The countries which were reported in the included studies are presented in Fig. 2.

The nine included studies showed evidence of cervical cancer among HIV-infected women and distribution of HPV infection and cervical abnormalities among HIVpositive individuals [90-98]. Five studies generalized about HIV and anal cancer [92-94, 96, 98]; only one reported about HIV and penile cancer [93]. Two studies $[93,98]$ generally reported about HIV and its association with head and neck cancers, and one [93] reported about vaginal cancer, vulvar cancer, and penile cancer. Figure 3 presents the number of included studies that reported on different anatomic cancer sites.

All included studies predominantly reported on women, followed by men and man having sex with man (MSM), except for one which generalized on children and adolescents [90]. The age of the population was not included in most studies, and only one study focused on women of 20 to 60 years old with an average age of 38 years [97]. The total number of participants from all the included studies was 16,351. The characteristics of the included studies are presented on Table 1.
A total of 120 studies were excluded from this study as they did not meet the inclusion criteria for this study. Of those 74 studies that underwent full manuscript review, 65 of them were found to have no valuable data for analysis in this study. A total of 53 articles did not report anything about study setting of interest which is SSA [1, 26-79], 7 did not report anything about HIV and HPV-related cancers [2, 41, 79-83], and 5 reported about HIV but not HPV-related cancers [85-89].

\section{Quality of evidence from included primary studies}

From the included ten studies, two primary studies underwent methodological quality assessment using the appropriate section of the Mixed Methods Appraisal Tool (MMAT)-Version 201 1[25]. Both studies scored 100\% [97, 98] (Additional file 3: Table S3). The remaining eight included studies were not appraised for quality because they were not primary studies.

\section{Findings of the studies}

The scoping review revealed findings about HPV-related cancer and their interplay with HIV. These cancers are cervical cancer, anal cancer, vulvar and vaginal cancers, head and neck cancers, and penile cancer.

\section{Cervical cancer}

The nine included studies reported about cervical cancer, HPV, and HIV [90-98]. The number of women living with HIV ranges was estimated to be less than 1000 cases in Comoros to 3.2 million in South Africa [95], whereas according to Bosch et al., HIV-positive women had two- to 22-folds increase risk of developing cervical cancer as compared to HIV-negative women [90]. Two studies demonstrated a 2.4 standard incidence ratio (SIR) of cervical cancer in HIV-positive women from Uganda AIDS-Cancer Registry Match Study [99], and the second from Senegal showed a substantial increase

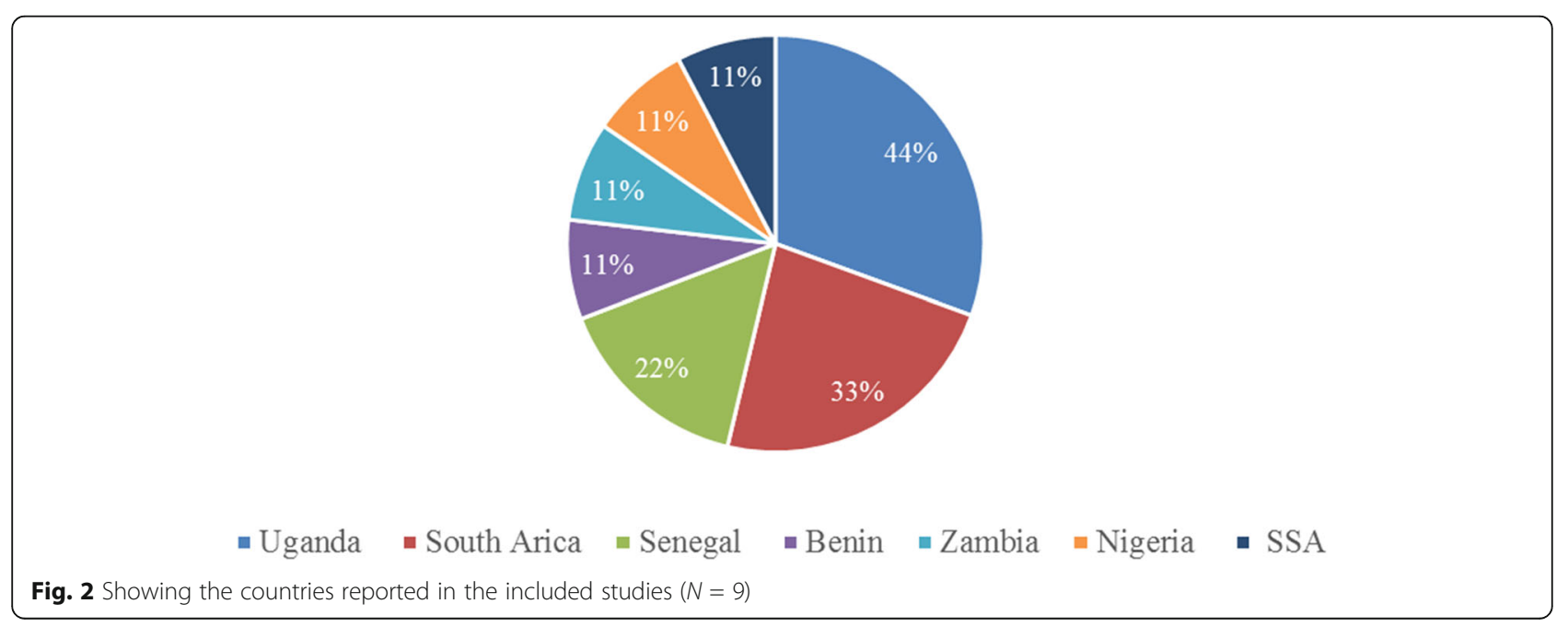




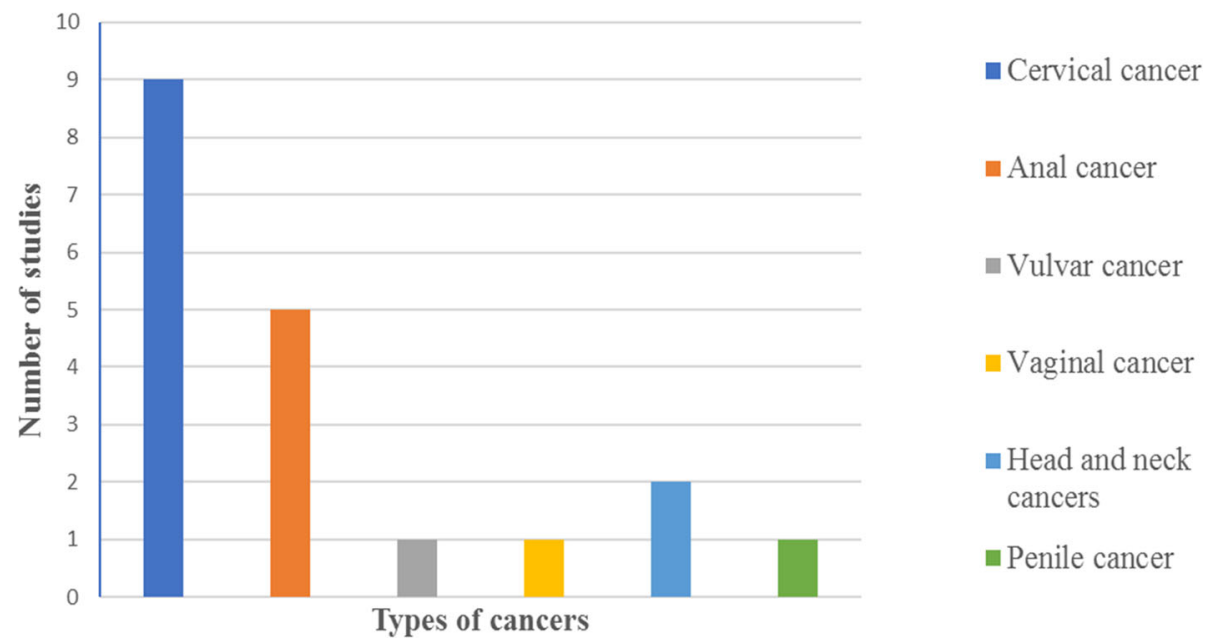

Fig. 3 Showing the number of included studies reported on different cancers in the study $(N=9)$

in the risk of invasive cervical cancer (ICC) which was observed with OR of 6.5 for ICC (95\% CI 2.1-19.8) in HIVinfected women compared with the control group of HIVnegative women [100]. The incidence of cervical cancer in a linkage of 15,000 HIV-infected individuals from Kyadondo County in Uganda reported 70 per 100,000 women-years and an SIR of 2.7 among HIV-infected women as compared to HIV-uninfected women [91]. Another study in Nigeria reported a two-fold higher risk of cervical cancer in people living with HIV/AIDS [97]. Two recent reviews have shown that HIV positivity is associated with increased prevalence of cervical HPV infection $[92,96]$ and cervical intraepithelial neoplasia (CIN) [96]. Furthermore, the study demonstrated a higher number of CIN among South African HIV-positive women as compared to HIV-negative women [96].

Recent review performed by Palesky has shown that HIV positivity is associated with increased prevalence of cervical HPV infection and cervical intraepithelial neoplasia (CIN) [96]. Furthermore, the study demonstrated a higher number of CIN among South African HIVpositive women as compared to HIV-negative women [96]. It has been reported that HIV-infected women have a higher prevalence and persistence of HPV infection, an increased risk for abnormal Pap smears and cervical cancer [97]. It was also confirmed by a transversal case control study conducted in Benin, aimed at verifying the HPV genotypes among women living with HIV and treated with ARV compared to women with no HIV infection that focus on HIV and HPV-related cancers [97]. In the study, only 5 had low-grade squamous intraepithelial lesion (LSIL), one had high-grade squamous intraepithelial lesion (HSIL), and 4/86 (5\%) had cervical dysplasia among HIV-infected women. However, highrisk HPV (HR-HPV) counts was higher among groups with HIV infections $(n=43)$ compared to the HIVnegative group. Additionally, $\mathrm{Hr}-\mathrm{HPV}$ infection was significantly high $(27 / 86=31 \%)$ in HIV-positive women compared to HIV-negative women $(20 / 86=23 \%)$. The study further highlighted that among the HIV-negative group, one woman with HPV and no lamin A/C developed cervical lesions and two women with no HPV but with total absence of lamin A/C developed cervical lesions [96]. A review by Louie et al. also reported that HIV-infected women are at a higher risk of being infected with Hr-HPV and are at a higher risk for persistence and associated cervical disease progression than HIV-uninfected women [95].

A review by Firnhaber et al. showed that HIV-infected women have a higher prevalence of HPV infection and cervical abnormalities compared to HIV-seronegative women throughout the world [92], and this was confirmed by three studies [101-103]. The first study was conducted in Cape Town, South Africa, among 400 untreated HIV-1-infected women who underwent HPV and cervical screening; the results showed $68 \%$ of women were positive for HR HPV DNA types and 35 and $13 \%$ of these women had LSIL and HSIL, respectively, on Papanicolaou (Pap) smears [101]. The second study conducted in Zambia among 145 women found that $98 \%$ of HIV-infected women harbored at least one type of HPV ( $85 \%$ had an HR HPV type), with a median of four types per participant; HPV type 52 was most the common at $37.2 \%$, with types $16(17.2 \%)$ and $18(13.1 \%)$ present in far fewer women [101]. Evidenced by the third study conducted in South Africa, among 148 HIVinfected women showed comparable results, with $95 \%$ of HIV-infected women harboring HPV [103]. One multicenter study from Uganda found HPV distribution in 107 HIV-infected and 309 HIV-uninfected women with 
Table 1 Characteristics of the included studies

\begin{tabular}{|c|c|c|c|c|c|c|c|c|}
\hline \multirow{3}{*}{$\begin{array}{l}\text { Author } \\
\text { and date } \\
\\
\text { Bosch, } \\
2013 \text { [90] }\end{array}$} & \multicolumn{3}{|c|}{ Study population } & \multirow{3}{*}{$\begin{array}{l}\text { Study } \\
\text { setting } \\
\\
\text { SSA }\end{array}$} & \multirow{3}{*}{$\begin{array}{l}\text { Geographical } \\
\text { location } \\
\\
\text { Not } \\
\text { specified }\end{array}$} & \multirow{3}{*}{$\begin{array}{l}\text { Type of cancer i } \\
\text { ndicated } \\
\text { Cervical cancer, a } \\
\text { nal cancer }\end{array}$} & \multirow{3}{*}{$\begin{array}{l}\text { Study } \\
\text { design } \\
\\
\text { Review }\end{array}$} & \multirow{3}{*}{$\begin{array}{l}\text { Outcome } \\
\text { HIV-positive women had two- to 22-folds } \\
\text { increase risk of developing cervical cancer } \\
\text { as compared to HIV-negative women }\end{array}$} \\
\hline & \multicolumn{3}{|c|}{$\begin{array}{l}\text { Gender and age } \\
\text { Number or population } \\
\text { percentage type }\end{array}$} & & & & & \\
\hline & $\begin{array}{l}\text { Women, } \\
\text { children, } \\
\text { men }\end{array}$ & Not specified & Not specified & & & & & \\
\hline $\begin{array}{l}\text { Brickman, } \\
2015 \text { [91] }\end{array}$ & $\begin{array}{l}\text { Female, } \\
\text { male }\end{array}$ & Not specified & $\begin{array}{l}15,000 \text { HIV-infected } \\
\text { individuals }\end{array}$ & $\begin{array}{l}\text { SSA } \\
\text { Uganda }\end{array}$ & $\begin{array}{l}\text { Kyadondo } \\
\text { County }\end{array}$ & $\begin{array}{l}\text { Cervical anal } \\
\text { cancer }\end{array}$ & Review & $\begin{array}{l}\text { Incidence of cervical cancer was reported } \\
\text { to be } 70 \text { per } 100,000 \text { women-years and a } \\
\text { SIR of } 2.7 \text { among HIV-infected women as } \\
\text { compared to HIV-uninfected women }\end{array}$ \\
\hline $\begin{array}{l}\text { Capo-chichi, } \\
2016 \text { [97] }\end{array}$ & $\begin{array}{l}\text { Women } \\
\text { (sexually } \\
\text { active) }\end{array}$ & $\begin{array}{l}20 \text { to } 60 \text { years } \\
\text { old (average } \\
38 \text { years) }\end{array}$ & $\begin{array}{l}86=\text { control group } \\
86=\text { HIV-infected } \\
\text { women }\end{array}$ & Benin & Contonou & Cervical cancer & $\begin{array}{l}\text { Transversal } \\
\text { case control }\end{array}$ & $\begin{array}{l}\text { HIV-infected women have a higher } \\
\text { prevalence and persistence of HPV } \\
\text { infection, an increased risk for abnormal } \\
\text { Pap smears and cervical cancer } \\
\text {-The study further highlighted that among } \\
\text { the HIV-negative group, one woman with } \\
\text { HPV and no lamin A/C developed cervical } \\
\text { lesions and two women with no HPV but } \\
\text { with total absence of lamin A/C developed } \\
\text { cervical cancer } \\
\text {-Five had low-grade squamous intraepithelial0 } \\
\text { lesion (LSIL), one had high-grade squamous } \\
\text { intraepithelial lesion (HSIL), and } 4 / 86 \text { (5\%) } \\
\text { had cervical dysplasia among HIV-infected } \\
\text { women }\end{array}$ \\
\hline \multirow{2}{*}{$\begin{array}{l}\text { De Vuyst, } \\
2013 \text { [92] }\end{array}$} & \multirow{2}{*}{$\begin{array}{l}\text { Women } \\
\text { Men }\end{array}$} & \multirow[t]{2}{*}{ Not specified } & Not specified & SSA & \multirow{2}{*}{ Not } & \multirow{2}{*}{$\begin{array}{l}\text { Cervical cancer, } \\
\text { anal cancer }\end{array}$} & \multirow[t]{2}{*}{ Review } & \multirow{2}{*}{$\begin{array}{l}\text {-HIV positivity is associated with increased } \\
\text { prevalence of cervical HPV infection } \\
\text {-HIV-infected individuals who live longer } \\
\text { on CART may be at increased risk of } \\
\text { persistent HPV infection and precancerous } \\
\text { CIN progressing to cervical cancers }\end{array}$} \\
\hline & & & $\begin{array}{l}379 \text { HIV-negative } \\
\text { and } 107 \text { HIV-positive } \\
\text { women with ICC }\end{array}$ & Uganda & & & & \\
\hline \multirow[t]{3}{*}{$\begin{array}{l}\text { Firnhaber, } \\
2012 \text { [93] }\end{array}$} & \multirow{3}{*}{$\begin{array}{l}\text { Women } \\
\text { Men } \\
\text { MSM }\end{array}$} & \multirow[t]{3}{*}{ Not specified } & 400 & $\begin{array}{l}\text { South } \\
\text { Africa }\end{array}$ & \multirow[t]{3}{*}{ Cape Town } & \multirow{3}{*}{$\begin{array}{l}\text { Cervical cancer } \\
\text { Anal cancer } \\
\text { Oropharyngeal } \\
\text { cancer } \\
\text { Vaginal cancer } \\
\text { Vulvar cancer }\end{array}$} & \multirow[t]{3}{*}{ Review } & \multirow{3}{*}{$\begin{array}{l}\text {-HIV-infected women have a higher } \\
\text { prevalence of HPV infection and cervical } \\
\text { abnormalities compared to HIV-seronegative } \\
\text { women throughout the world } \\
\text {-Studies confirmed that HIV-positive } \\
\text { women harbored high-risk HPV } \\
\text {-HPV-related anal cancer is increasing in } \\
\text { both HIV-infected women and men } \\
\text { despite ARV treatment } \\
\text {-Vulvar cancer occurs in HIV-infected } \\
\text { women who are less than } 40 \text { years } \\
\text {-HIV-infected people appear to have a } \\
\text { rate of two to four times higher of } \\
\text { oropharyngeal cancer than HIV- } \\
\text { uninfected populations } \\
\text {-The risk of invasive penile cancer is } \\
\text { estimated to be } 20 \text { times higher } \\
\text { among HIV-infected men as compared } \\
\text { to HIV-uninfected men }\end{array}$} \\
\hline & & & 145 & Zambia & & & & \\
\hline & & & 148 & $\begin{array}{l}\text { South } \\
\text { Africa } \\
\text { SSA }\end{array}$ & & & & \\
\hline $\begin{array}{l}\text { Heard, } \\
2011[94]\end{array}$ & Women & Not specified & Not specified & $\begin{array}{l}\text { SSA } \\
\text { Senegal }\end{array}$ & $\begin{array}{l}\text { Not } \\
\text { specified }\end{array}$ & Cervical cancer & Review & $\begin{array}{l}\text { Study from Senegal reported a substantial } \\
\text { increase in the risk of invasive cervical } \\
\text { cancer (ICC) which was observed with } \\
\text { OR of } 6.5 \text { for ICC ( } 95 \% \text { CI } 2.1-19.8) \text { in } \\
\text { HIV-infected women compared with } \\
\text { control group of HIV-negative women }\end{array}$ \\
\hline $\begin{array}{l}\text { Jedy-Agba, } \\
2016 \text { [98] }\end{array}$ & $\begin{array}{l}\text { Female, } \\
\text { male }\end{array}$ & Not specified & Not specified & $\begin{array}{l}\text { SSA } \\
\text { Nigeria }\end{array}$ & $\begin{array}{l}\text { Not } \\
\text { specified }\end{array}$ & $\begin{array}{l}\text { Cervical cancer } \\
\text { Oropharyngeal } \\
\text { cancer } \\
\text { Anal cancer }\end{array}$ & Quantitative & $\begin{array}{l}\text { Study in Nigeria reported a two-fold } \\
\text { higher risk of cervical cancer in people } \\
\text { living with HIV/AIDS }\end{array}$ \\
\hline $\begin{array}{l}\text { Louie, } \\
2009 \text { [95] }\end{array}$ & Women & Not specified & Not specified & $\begin{array}{l}\text { South } \\
\text { Africa } \\
\text { Uganda }\end{array}$ & $\begin{array}{l}\text { Not } \\
\text { specified }\end{array}$ & $\begin{array}{l}\text { Invasive cervical } \\
\text { cancer }\end{array}$ & Review & $\begin{array}{l}\text { HIV-infected women are at higher risk } \\
\text { of being infected with Hr-HPV and are } \\
\text { at a higher risk for persistence and } \\
\text { associated cervical disease progression } \\
\text { than HIV-uninfected women }\end{array}$ \\
\hline $\begin{array}{l}\text { Palefsky, } \\
2006 \text { [96] }\end{array}$ & $\begin{array}{l}\text { Men who } \\
\text { have sex } \\
\text { with men } \\
\text { Women }\end{array}$ & Not specified & Not specified & $\begin{array}{l}\text { SSA } \\
\text { South } \\
\text { Africa } \\
\text { Uganda } \\
\text { Senegal }\end{array}$ & $\begin{array}{l}\text { Not } \\
\text { specified }\end{array}$ & $\begin{array}{l}\text { Anal cancer } \\
\text { Cervical cancer }\end{array}$ & Review & $\begin{array}{l}\text { HIV positivity is associated with increased } \\
\text { prevalence of cervical HPV infection and } \\
\text { cervical intraepithelial neoplasia }\end{array}$ \\
\hline
\end{tabular}


ICC [92]. It has been shown that HIV-infected individuals who live longer on CART may be at increased risk of persistent HPV infection and precancerous CIN progressing to cervical cancers [92]. Although there is evidence reported on the association of HIV, HPV, and cervical cancer, more studies should be conducted to investigate the contribution of HPV in cervical cancer cases among HIV-infected women. Again, more studies to investigate the distinguishable effect of ART among HIV-infected women are required. Furthermore, studies to investigate to what extent does HIV confers to the development of cervical HPV attributable cancer in HIVinfected women are recommended.

\section{Anal cancer}

Five of the included studies generally reported about anal cancer, HPV, and HIV [92-94, 96, 98]. One study showed that the knowledge of the prevalence of anal cancer in HIV-infected men and women in resourcelimited countries is very limited, yet on the other hand, HPV-related anal cancer is increasing in both HIVinfected women and men despite ARV treatment [93]. Studies have demonstrated high prevalence of anal HPV infection, anal precancerous lesions, and anal cancer in HIV-positive individuals in both men and women [94]. Two studies have shown that anal HPV infection and anal intraepithelial neoplasia (AIN) are remarkably common among both HIV-positive and HIV-negative women and the incidence is elevated in both HIVpositive and HIV-negative MSM [96, 98]. A review published by De Vuyst et al. show that there is an increased risk of persistent HPV infection and precancerous AIN that progresses to anal cancer among HIV-infected individuals [92]. Despite the revealed findings, it is shown that more studies to determine the prevalence or burden of anal cancer among HIV-infected men, women, and MSM are missing. Further studies to determine whether the use of ART result in regression of anal HPV lesions in HIV-infected individuals are recommended.

\section{Vulvar and vaginal cancers}

One of the nine included studies reported about vulvar and vaginal cancers and HIV [92]. A report in the literature indicated that vulvar cancer occurs in HIV-infected women who are less than 40 years [93]. It is often seen in the post-menopausal stage in the 7th or 8th decade of life [94]. Vaginal cancer and vaginal HPV infection are also reported to be higher in HIV-infected patients than in HIV-seronegative women, and this cancer occurs at a younger age in HIV-infected individuals [93]. Further studies to assess the risk of acquiring vaginal and vulvar cancers among HIV-infected women are missing.

\section{Head and neck cancers}

Two from the included studies generalized about oropharyngeal cancer and HIV [93, 98]. It has been reported that other HPV-attributable cancers like oropharyngeal cancers have also been linked with HIV infection [98] and the HIV-infected people appear to have a rate of two to four times higher of oropharyngeal cancer than that of HIV-uninfected populations [93]. Although evidence between HIV and oropharyngeal cancer was identified, it was not sufficient to draw a conclusion on the interplay between HIV and HPV-related head and neck cancers as it reported on oropharyngeal cancers; instead, more studies are recommended.

\section{Penile cancer}

One of the nine included studies generalized about penile cancer and HIV [93]. According to the review published by Firnhaber et al., the risk of invasive penile cancer is estimated to be 20 times higher among HIVinfected men as compared to HIV-uninfected men [92]. Moreover, a second study estimated penile cancer risk to be four times higher in HIV-infected men [93]. More studies are still required on the interaction between HPV-related penile cancer and HIV; one study is insufficient.

\section{Discussion}

The study was aimed at exploring the evidence on the interplay of HIV and human papillomavirus-related cancers in SSA. This scoping review provided a general overview and evidence on the interplay of HIV with cancer of the cervix, anus, vulvar, vaginal, penile, and head and neck in SSA. This scoping review presented evidence from six countries within SSA; only two studies were conducted in urban areas and not specified in most of the studies. Again, generally there is a lack of studies conducted specifically on males as opposed to those conducted on females. The findings demonstrated a gap in literature on HPV-related cancers among HIVinfected individuals in many countries within SSA and lack of research in rural areas and poor participation among men. Our results show that there is limited evidence to confirm the presence of HPV genotypes on different anatomic cancer sites among PLHIV. It also shows scarcity of studies aimed at evaluating the risk of developing HPV-related cancers among HIV-infected people. Although evidence on interplay of HIV between vulvar cancer, vaginal cancers, head and neck cancers, and penile cancer has been identified, it was not sufficient to make a generalization and conclusion due to the limited evidence.

This study shows that the prevalence of cervical HPV infection and CIN is increased with HIV positivity [96]. In agreement with our findings, cohort studies provided 
persuasive evidence that the risk of acquiring cervical HPV infection is higher in HIV-positive women as compared to HIV-negative women [104-108]. This scoping review shows in the study conducted in Benin that five of HIV-infected woman had LSIL and one had HSIL, respectively [97], and results from another study in South Africa reported 35\% LSIL and 13\% HSIL among HIVinfected women [101]. Similarly, the prevalence of LSIL and HSIL in women infected with HIV is reported as 28.6 and $14 \%$ in the UK [109], 15.4 and $7.9 \%$ in the USA [110], and again 21.0 and $2.8 \%$ in a European cohort [111]. Several studies from this scoping review shows that HIV-infected women harbor different Hr-HPV genotypes [97, 101-103]. In line with this study, persistent HPV types were shown to be $24 \%$ in HIV-positive women versus $4 \%$ in HIV-negative women [112] and again a broader range of both $\mathrm{Hr}-\mathrm{HPV}$ and low-risk HPV types were found in HIV-positive women as compared to the HIV-negative women [113-115].

This study has been shown that knowledge on the prevalence of anal cancer in HIV-infected men and women in resource-limited countries is very limited, yet on the other hand, HPV-related anal cancer is increasing in both HIV-infected women and men despite ARV treatment [93]. In line with this, a study conducted to check the incidence and risk factors for anal cancer in HIV-positive people showed that anal cancer incidence was extensively higher in the ART era as compared to the pre-ART era [115]. This study findings generalized about head and neck cancers; however, a meta-analysis of cancer incidence in people with HIV demonstrated that HIV positive individuals are 2.32 times (95\% CI 1.65 to 3.25 ) as likely to develop oral cavity or pharyngeal cancers as compared to HIV-negative individuals [1].

Despite the limited literature in SSA, in the USA, the estimated cancer risk among HIV-infected individuals as compared to the general population has been estimated to be as high as 29 times increased for anal cancer, 4 times for penile cancer, 6 times for vulvar and vaginal cancer as well as cervical cancer, respectively [1]. The findings of this study demonstrate a need for more research investigating the HPV-related cancer among HIV-infected population in SSA.

\section{Strengths and limitations of the study}

An important strength of this study is that there has been a comprehensive search of relevant studies to be included in this scoping review with no limitation on publication dates and language. This scoping review methodology has allowed for the inclusion of different study designs, and a systematic approach was used to identify relevant studies, charting, and analysis of outcomes $[20,23]$. Studies were selected according to the PEO (population, exposure, and outcomes) framework as it was the appropriate heuristic to use based on the framed research question. In addition, the results of the scoping review were presented following the PRISMA recommendation which ensured complete and transparent reporting (Additional file 4: Table S1). Transparent methodological quality assessments of the included primary studies using the recommended MMAT tool assess the risk of bias from the included studies. The study was not limited to a specific population group; this allowed for extensive exploration of HPV-related cancers in PLHIV on different age groups, gender, and different geographical locations in SSA.

Despite the strengths reported for this study, there is a limitation as well. The study was limited with the exclusion of qualitative studies as the research question is more epidemiological, hence the use of PEO framework. Qualitative research was not qualified to be included in this scoping review; therefore, it might have resulted in omission of data.

\section{Implications for research}

This study shows limited evidence on the interaction of HIV and HPV-related cancers especially on anal cancer across all genders, vaginal cancer, vulvar cancer, head and neck cancers, and penile cancer. We hope this study results will prompt further studies to provide better insights on the natural history of HPV-related cancers. More studies to evaluate the risk of developing HPVrelated cancers among PLHIV are recommended. Additionally, more future studies to be conducted at different countries within SSA and in rural areas are needed. It also calls for recruitment of more males to participate in research.

\section{Implications for practice}

This study revealed the need for policy makers in public health to take note on the development of HPVattributable cancers among PLHIV when planning and making decisions, bearing in mind that HIV-infected individuals who live longer on ART may be at increased risk of persistent HPV infection [92]. Our study findings also suggest that HPV infection should be evaluated at various stages of HIV, such as during the initiation of ART and with the long-term use of ART among all infected individuals (men, women, and children). This study's findings further suggest that more effective control interventions among PLHIV are needed to reduce the burden of HPV-attributable cancers among this group. Moreover, this scoping review findings suggested there were limited research among populations in resource-limited settings; hence, future investigations should consider including populations who live in such settings. 


\section{Conclusion}

This study enabled the authors to provide evidence on the interplay of HIV and HPV-related cancers in SSA. Although this study demonstrated shortage of evidence from published studies on the interaction between HIV and HPV-attributable cancers on all identified anatomic sites, high number of studies reported the association of HIV positivity with increased prevalence of HPV infection on different anatomic sites, which will result in increased burden of HPV-related cancers among PLHIV. Therefore, a meta-analysis study is recommended to confirm this association. Furthermore, primary studies with robust study designs aimed at investigating the risk of developing HPV-related cancers among PLHIV in SSA are recommended. Furthermore, primary studies with robust study designs aimed at investigating the risk of developing HPV-related cancers among PLHIV in SSA are recommended.

\section{Supplementary information}

Supplementary information accompanies this paper at https://doi.org/10. 1186/s13643-020-01354-1.

Additional file 1: Table S1. Electronic database search results for title screening.

Additional file 2: Table S1. Calculation of degree of agreement.

Additional file 3: Table S1. MMAT quality assessment tool.

Additional file 4: Table S1. PRISMA checklist.

\section{Abbreviations}

AIDS: Acquired immunodeficiency syndrome; AIN: Anal intraepithelial neoplasia; ART: Antiretroviral therapy; CIN: Cervical intraepithelial neoplasia; HIV: Human immunodeficiency virus; HPV: Human papillomavirus; HrHPV: High-risk HPV; HSIL: High-grade squamous intraepithelial lesion; ICC: Invasive cervical cancer; IARC: International Agency for Research on Cancer; LMIC: Low- and middle-income countries; LSIL: Low-grade squamous intraepithelial lesion; MeSH: Medical Subject Headings; MMAT: Mixed Methods Appraisal Tool; MSM: Men who have sex with men; PLHIV: People living with HIV; PRISMA: Preferred Reporting Items for Systematic Reviews and Meta-Analyses; SSA: Sub-Saharan Africa; WHO: World Health Organization

\section{Acknowledgements}

We would like to thank the following institutions: College of Health Sciences and Library services at the University of KwaZulu-Natal for providing with resources to help us with setting up and conducting this research study.

\section{Authors' contributions}

KMBL, TG, and TPM-T conceptualized and designed the study. KMBL prepared the first draft of the study, and DK and TPM-T contributed in the abstract, full article screening, and quality assessment of the included studies. TPM-T contributed in the synthesis of data and the design of the sifting and data extraction processes. TG and TPM-T reviewed the manuscript. All authors reviewed the draft versions of the manuscript and approved the final version of the manuscript.

\section{Funding}

This study was funded by the University of KwaZulu-Natal, College of Health Sciences Research Scholarship.

\section{Availability of data and materials}

The data reported and supporting this paper was sourced from the existing literature and are therefore available through the detailed reference list.

\section{Ethics approval and consent to participate}

This paper is a scoping review which strictly relied on the review of existing literature. Since there were no animal or human participants in this study, ethical approval is not required.

\section{Consent for publication}

Not applicable

\section{Competing interests}

The authors declare that they have no competing interests.

Received: 27 August 2018 Accepted: 8 April 2020

Published online: 22 April 2020

References

1. Grulich $A E$, van Leeuwen MT, Falster MO, Vajdic CM. Incidence of cancers in people with HIV/AIDS compared with immunosuppressed transplant recipients: a meta-analysis. Lancet. 2007;370(9581):59-67.

2. Parkin DM, Bray F. Chapter 2: the burden of HPV-related cancers. Vaccine. 2006;24(suppl 3):S11-25.

3. Gillison ML, Shah KV. Chapter 9: role of mucosal human papillomavirus in non-genital cancers. J Natl Cancer Inst Monogram. 2003;31:57-65.

4. Frisch M, Biggar RJ, Goedert JJ. Human papillomavirus-associated cancers in patients with human immunodeficiency virus infection and acquired immunodeficiency syndrome. J Natl Cancer Inst. 2000:92(18):1500-10.

5. Clifford GM, Polesel J, Rickenbach M, et al. Cancer risk in the Swiss HIV cohort study: associations with immunodeficiency, smoking, and highly active antiretroviral therapy. J Natl Cancer Inst. 2005;97(6):425-32.

6. International Collaboration on HIV and Cancer. Highly active antiretroviral therapy and incidence of cancer in human immunodeficiency virus infected adults. J Natl Cancer Inst. 2000;92(22):1823-30.

7. Frisch M, Biggar RJ, Engels EA, Goedert JJ. Association of cancer with AIDSrelated immunosuppression in adults. JAMA. 2001;285(13):1736-45.

8. Palefsky JM. Human papillomavirus infection and anogenital neoplasia in human immunodeficiency virus-positive men and women. J Natl Cancer Inst Monog .1998; (23):15 -20.

9. Palefsky JM, Holly EA. Chapter 6: immunosuppression and co-infection with HIV. J Natl Cancer Inst Monogram. 2003;31:41-6.

10. Silverberg MJ, Abrams DI. AIDS-defining and non-AIDS-defining malignancies: cancer occurrence in the antiretroviral therapy era. Current Opinion in Oncology 2007; 19:446-451. [PubMed: 17762569].

11. Silverberg MJ, Neuhaus J, Bower M, et al. Risk of cancers during interrupted antiretroviral therapy in the SMART study. AIDS 2007; 21(14):1957-1963. [PubMed: 17721103].

12. UNAIDS (2017) 'Ending AIDS: Progress towards the 90-90-90 targets'.

13. Silverberg MJ, Lau B, Achenbach CJ, et al. Cumulative incidence of cancer among persons with HIV in North America: a cohort study. Ann Intern Med. 2015;163(7):507-18.

14. Coghill AE, Shiels MS, Suneja G, Engels EA. Elevated cancer-specific mortality among HIV-infected patients in the United States. J Clin Oncol. 2015;33(21): 2376-2383. [PMC free article] [PubMed].

15. Biggar RJ, Chaturvedi AK, Goedert JJ, Engels EA. AIDS-related cancer and severity of immunosuppression in persons with AIDS. J Natl Cancer Institute. 2007;99(12):962-72 [PubMed: 17565153]. This paper is an assessment of the link between level of immunosuppression and risk of several AIDs-defining cancers including cervical cancer.

16. Diamond C, Taylor TH, Aboumrad T, et al. Increased incidence of squamous cell anal cancer among men with AIDS in the era of highly active antiretroviral therapy. Sexually Transmitted Dis 2005; 32(5):314-320. [PubMed: 15849533].

17. Bower M, Powles T, Newsom-Davis T, et al. HIV-associated anal cancer: has highly active antiretroviral therapy reduced the incidence or improved the outcome? J Acquired Immune Deficiency Syndromes 2004; 37(5):1563-1565. [PubMed: 15577408].

18. Koutsky LA, FUTURE II Study Group. Quadrivalent vaccine against human papillomavirus to prevent high-grade cervical lesions. NEJM. 2007;256(19): 1915-27.

19. Garland SM, Hernandez-Avila M, Wheeler CM, et al. Quadrivalent vaccine against human papillomavirus to prevent anogenital diseases. NEJM 2007; 356(19):1928-1943. [PubMed: 17494926]. 
20. Stier E. Human papillomavirus related diseases in HIV-infected individuals. CurrOpinOncol. 2008;20(5):541-6. https://doi.org/10.1097/CCO. Ob013e3283094ed8.

21. Hendry M, Pasterfield D, Lewis $R$, et al. Are women ready for the new cervical screening protocol in England? A systematic review and qualitative synthesis of views about human papillomavirus testing. Br J Cancer. 2012; 107:243-54.

22. Hendry M, Lewis R, Clements A, et al. "HPV? Never heard of it!": a systematic review of girls' and parents' information needs, views and preferences about human papillomavirus vaccination. Vaccine. 2013;31:5152-67.

23. Lekoane, et al. Mapping evidence on the burden of human papillomavirusrelated cancers in sub-Saharan Africa: scoping review protocol. Syst Rev. 2017;6:229. https://doi.org/10.1186/s13643-017-0623-3.

24. Arksey H, O'Malley L. Scoping studies: towards a methodological framework. Int J Soc Res Methodology. 2005;8(1):19-32.

25. Levac D, Colquhoun H, O'Brien KK. Scoping studies: advancing the methodology. Implementation Science. 2010;5(1):69.

26. Pluye $P$, et al. Proposal: a mixed methods appraisal tool for systematic mixed studies reviews. Montréal: McGill University; 2011. p. 1-8.

27. Moher D, Shamseer L, Clarke M, Ghersi D, Liberati A, Petticrew M, Shekelle P, Stewart LA. Preferred reporting items for systematic review and metaanalysis protocols (PRISMA-P) 2015 statement. Syst Rev. 2015;4(1):1.

28. Adelstein DJ, Rodriguez CP. Human papillomavirus: changing paradigms in oropharyngeal cancer. Current oncology reports. 2010;12(2):115-20.

29. Atlin CR, Chung J, Goldstein D, Johnson-Obaseki S, Bloom JA, Jaakkimainen $L$, et al. Assessing the need for an educational intervention for primary care practitioners on HPV-related oropharyngeal cancer. University of Toronto Med J. 2016;94(1):17-21.

30. Auluck A, Hislop G, Bajdik C, Poh C, Lewei Z, Rosin M. Trends in oropharyngeal and oral cavity cancer incidence of human papillomavirus (HPV)-related and HPV-unrelated sites in a multicultural population. Cancer (0008543X).2010;116(11):2635-2644.

31. Azvolinsky A. Concerned about HPV-related cancer rise, researchers advocate boosting HPV vaccination rates. JNCl: Journal of the National Cancer Institute. 2013;105(18):1335-6.

32. Barroca HM, Pontes P, Amendoeira IM. Anal HR-HPV prevalence assessed with the cobas ${ }^{\circledast} \mathrm{HPV}$ test in an HIV-infected population of men who have sex with men. Porto Biomedical Journal. 2016;1(1):29-31.

33. Barzon L, Cappellesso R, Peta E, Militello V, Sinigaglia A, Fassan M, et al Profiling of expression of human papillomavirus-related cancer miRNAs in penile squamous cell carcinomas. The American Journal of Pathology. 2014; 184(12):3376-83.

34. Beachler DC, Weber KM, Margolick JB, Strickler HD, Cranston RD, Burk RD, et al. Risk factors for oral HPV infection among a high prevalence population of HIV-positive and at-risk HIV-negative adults. Cancer Epidemiology and Prevention Biomarkers. 2011.

35. Best SR, Niparko KJ, Pai SI. Biology of human papillomavirus infection and immune therapy for HPV-related head and neck cancers. Otolaryngologic Clinics of North America. 2012;45(4):807-22.

36. Beachler DC, Abraham AG, Silverberg MJ, Jing Y, Fakhry C, Gill MJ, et al. Incidence and risk factors of HPV-related and HPV-unrelated head and neck squamous cell carcinoma in HIV-infected individuals. Oral oncology. 2014; 50(12):1169-76.

37. Biron VL, Cote DW, Seikaly H. Oropharyngeal squamous cell carcinoma and human papillomavirus-associated cancers in women: epidemiologic evaluation of association. J Otolaryngol Head Neck Surg. 2011;40(Suppl 1): S65-9.

38. Bodelon C, Untereiner ME, Machiela MJ, Vinokurova S, Wentzensen N. Genomic characterization of viral integration sites in HPV-related cancers. Int J Cancer. 2016;139(9):2001-11.

39. Borget I, Abramowitz L, Mathevet P. Economic burden of HPV-related cancers in France. Vaccine. 2011;29(32):5245-9.

40. Bosch F, Lorincz A, Munoz N, Meijer C, Shah K. The causal relation between human papillomavirus and cervical cancer. J Clin Pathol. 2002;55(4):244-65.

41. Bosch FX, Manos MM, Muñoz N, Sherman M, Jansen AM, Peto J, et al. Prevalence of human papillomavirus in cervical cancer: a worldwide perspective. JNCl: Journal of the National Cancer Institute. 1995;87(11):796802.

42. Chaturvedi AK. Beyond cervical cancer: burden of other HPV-related cancers among men and women. J Adolescent Health. 2010;46(4 Suppl):S20-6.
43. Chaturvedi AK, Engels EA, Anderson WF, Gillison ML. Incidence trends for human papillomavirus-related and-unrelated oral squamous cell carcinomas in the United States. Journal of clinical oncology. 2008;26(4): 612-9.

44. Chaturvedi AK, Madeleine MM, Biggar RJ, Engels EA. Risk of human papillomavirus-associated cancers among persons with AIDS. Journal of the National Cancer Institute. 2009;101(16):1120-30.

45. L-m C, Rubin M, Smith-McCune K. Screening and treatment of HPV-related diseases in gynecologic practice. Seminars Colon Rectal Surg. 2004;15(4): 201-9.

46. Chow LT. Model systems to study the life cycle of human papillomaviruses and HPV-associated cancers. Virologica Sinica. 2015;30(2):92-100.

47. Clemente N, Alessandrini L, Vaccher E, De Paoli A, Buttignol M, Canzonieri V, et al. Multiple preinvasive and invasive HPV-related lesions of the anogenital tract in a female patient with HIV infection: a case report. Medicine. 2017; 96(4):e5948-e.

48. Conway EL, Farmer KC, Lynch WJ, Rees GL, Wain G, Adams J. Quality of life valuations of HPV-associated cancer health states by the general population. Sexually transmitted infections. 2012;88(7):517-21.

49. Dillner J. Prevention of human papillomavirus-associated cancers. Semin Oncol. 2015;42(2):272-83.

50. D'souza G, Kreimer AR, Viscidi R, Pawlita M, Fakhry C, Koch WM, et al. Casecontrol study of human papillomavirus and oropharyngeal cancer. New England Journal of Medicine. 2007;356(19):1944-56.

51. Dunne EF, Park IU. HPV and HPV-associated diseases. Infectious Disease Clinics of North America. 2013;27(4):765-78.

52. Joo Y-H, Lee Y-S, Cho K-J, Park J-O, Nam I-C, Kim C-S, et al. Characteristics and prognostic implications of high-risk HPV-associated hypopharyngeal cancers. PLOS ONE. 2013;8(11):16.

53. Katz A. CE: Human papillomavirus-related oral cancers: the nurse's role in mitigating stigma and dispelling myths. The American Journal of Nursing. 2017;117(1):34-9.

54. Kreuter A, Wieland U. Human papillomavirus-associated diseases in HIVinfected men who have sex with men. Current opinion in infectious diseases. 2009;22(2):109-14.

55. Krishnan A, Levine AM. Malignancies in women with HIV infection. Women's Health (London, England). 2008;4(4):357-68.

56. Levovitz $C_{t}$ Chen $D_{1}$ Ivansson $E_{1}$ Gyllensten U, Finnigan JP, Alshawish $\mathrm{S}$, et al TGFbeta receptor 1: an immune susceptibility gene in HPV-associated cancer. Cancer Res. 2014;74(23):6833-44.

57. Liu C-Y, Li F, Zeng Y, M-z T, Huang Y, Li J-T, et al. Infection and integration of high-risk human papillomavirus in HPV-associated cancer cells. Med Oncol (Northwood, London, England). 2015;32(4):109.

58. Mayeaux EJ Jr. Reducing the economic burden of HPV-related diseases. JAOA, 2008:108(4):S2-7.

59. Meyer MF, Huebbers CU, Siefer OG, Vent J, Engbert I, Eslick GD, et al. Prevalence and risk factors for oral human papillomavirus infection in 129 women screened for cervical HPV infection. Oral Oncology. 2014;50(1):2731.

60. Mirghani H, Sturgis EM, Aupérin A, Monsonego J, Blanchard P. Is there an increased risk of cancer among spouses of patients with an HPV-related cancer: a systematic review? Oral Oncology. 2017;67:138-45.

61. Nelson RA, Lai LL. Elevated risk of human papillomavirus-related second cancers in survivors of anal canal cancer. Cancer. 2017.

62. Neumann F, Jégu J, Mougin C, Prétet J-L, Guizard A-V, Lapôtre-Ledoux B, et al. Risk of second primary cancer after a first potentially-human papillomavirus-related cancer: a population-based study. Preventive Medicine. 2016;90:52-8.

63. Nicol AF, Monsonego J, editors. Summary of the Eurogin 2011 conference: highlighting the recent advances in HPV-related cancers.2011/11.

64. O'rorke M, Ellison M, Murray L, Moran M, James J, Anderson L. Human papillomavirus related head and neck cancer survival: a systematic review and meta-analysis. Oral Oncol. 2012;48(12):1191-201.

65. Ortiz AP, Perez-Irizarry J, Soto-Salgado M, Suarez E, Perez N, Cruz M, et al. Human papillomavirus-related cancers among people living with AIDS in Puerto Rico. Prev Chronic Dis. 2014;11:E80.

66. Paavonen J. Human papillomavirus infection and the development of cervical cancer and related genital neoplasias. International Journal of Infectious Diseases. 2007;11:S3-9.

67. Palefsky J. Human papillomavirus-related disease in people with HIV. Curr Opin HIV AIDS. 2009:4(1):52-6. 
68. Palefsky JM. Cutaneous and genital HPV-associated lesions in HIV-infected patients. Clin Dermatol. 1997;15(3):439-47.

69. Palefsky JM. Human papillomavirus-associated anal and cervical cancers in HIV-infected individuals: incidence and prevention in the antiretroviral therapy era. Curr Opin HIV AIDS. 2017;12(1):26-30.

70. Schiech L. Hpv-related cancer: an equal opportunity danger. Nursing. 2010; 40(10):22-9.

71. Shack L, Lau HY, Longlong H, Doll C, Hao D. Trends in the incidence of human papillomavirus-related noncervical and cervical cancers in Alberta, Canada: a population-based study. CMAJ Open. 2014;2(3):E127-E32.

72. Stier EA, Sebring MC, Mendez AE, Ba FS, Trimble DD, Chiao EY. Prevalence of anal human papillomavirus infection and anal HPV-related disorders in women: a systematic review. American Journal of Obstetrics and Gynecology. 2015;213(3):278-309.

73. Syrjänen S. Human papillomavirus infection and its association with HIV. Advances in dental research. 2011;23(1):84-9.

74. Tornesello ML, Perri F, Buonaguro L, Ionna F, Buonaguro FM, Caponigro F. HPV-related oropharyngeal cancers: from pathogenesis to new therapeutic approaches. Cancer letters. 2014;351(2):198-205.

75. Van der Zee RP, Richel O, De Vries H, Prins JM. The increasing incidence of anal cancer: can it be explained by trends in risk groups. The Netherlands journal of medicine. 2013;71(8):401-11.

76. Vivenza D, Lo Nigro C, Denaro N, Fortunato M, Monteverde M, Tonissi F, et al. E1 detection as prognosticator in human papillomavirus-positive head and neck cancers. Int J Biol Markers. 2016;31(2):0.

77. Wagner S, Sharma SJ, Wuerdemann N, Knuth J, Reder H, Wittekindt C, et al. Human papillomavirus-related head and neck cancer. Oncol Res Treat. 2017; 40(6):334-40.

78. Wakeham K, Kavanagh K. The burden of HPV-associated anogenital cancers. Curr Oncol Rep. 2014;16(9):402.

79. Kahn JA, Burk RD, Squires KE, Kapogiannis BG, Rudy B, Xu J, et al. Prevalence and risk factors for HPV in HIV-positive young women receiving their first HPV vaccination. JAIDS. 2012;61(3):390-9.

80. Forman D, de Martel C, Lacey CJ, Soerjomataram I, Lortet-Tieulent J, Bruni L, et al. Global burden of human papillomavirus and related diseases. Vaccine. 2012;30(Suppl 5):F12-23.

81. Muñoz N, Bosch FX, de Sanjosé S, Herrero R, Castellsagué X, Shah KV, et al. Epidemiologic classification of human papillomavirus types associated with cervical cancer. N Engl J Med. 2003;2003(348):518-27.

82. Oga EA, Schumaker LM, Alabi BS, Obaseki D, Umana A, Bassey I-A, et al. Paucity of HPV-related head and neck cancers (HNC) in Nigeria. PLoS ONE. 2016;11(4):1-9.

83. Lowy R, Schiller JT. Reducing HPV-associated cancer globally. Cancer Prevention Res (Philadelphia, Pa). 2012;5(1):18-23.

84. Gooi Z, Chan JY, Fakhry C. The epidemiology of the human papillomavirus related to oropharyngeal head and neck cancer. Laryngoscope. 2016;126(4): 894-900.

85. De Sanjosé S, Serrano B, Castellsagué X, Brotons M, Muñoz J, Bruni L, et al. Human papillomavirus (HPV) and related cancers in the Global Alliance for Vaccines and Immunization (GAVI) countries. WHO/ICO HPV Information Centre Report. Vaccine. 2012;30(suppl 4):D1-D83.

86. Olesen TB, Iftner T, Mwaiselage J, Kahesa C, Rasch V, Ngoma T, et al. Prevalence and type distribution of human papillomavirus among 1813 men in Tanzania and the relationship to HIV status. Sexually Transmitted Diseases. 2013;40(7):592-8.

87. Natunen K, Lehtinen J, Namujju P, Sellors J, Lehtinen M. Aspects of prophylactic vaccination against cervical cancer and other human papillomavirus-related cancers in developing countries. Infectious diseases in obstetrics and gynecology. 2011;2011.

88. Arbyn M, De Sanjosé S, Saraiya M, Sideri M, Palefsky J, Lacey C, et al. EUROGIN 2011 roadmap on prevention and treatment of HPV-related disease. International journal of cancer. 2012;131(9):1969-82.

89. Carroll KA, Pierce J, Kovarik CL. Perianal Bowen disease in a child with human immunodeficiency virus. Pediatric Dermatology. 2010;27(2):166-9.

90. Bosch FX, Broker TR, Forman D, Moscicki A-B, Gillison ML, Doorbar J, et al. Comprehensive control of human papillomavirus infections and related diseases. Vaccine. 2013;31:H1-H31.

91. Brickman C, Palefsky JM. Human papillomavirus in the HIV-infected host: epidemiology and pathogenesis in the antiretroviral era. Curr HIV/AIDS Rep. 2015;12(1):6-15.
92. De Vuyst H, Alemany L, Lacey C, Chibwesha CJ, Sahasrabuddhe V, Banura C, et al. The burden of human papillomavirus infections and related diseases in sub-Saharan Africa. Vaccine. 2013;31(Suppl 5):F32-46.

93. Firnhaber C, Wilkin T. Human papillomavirus vaccines: where do they fit in HIV-infected individuals? Current HIV/AIDS Reports. 2012;9(3):278-86.

94. Heard I. Human papillomavirus, cancer and vaccination. Cur Opin HIV AIDS. 2011;6(4):297-302

95. Louie KS, De Sanjose S, Mayaud P. Epidemiology and prevention of human papillomavirus and cervical cancer in sub-Saharan Africa: a comprehensive review. Tropical Medicine \& International Health. 2009;14(10):1287-302.

96. Palefsky J. Human papillomavirus-related tumors in HIV. Current opinion in oncology. 2006;18(5):463-8.

97. Capo-chichi CD, Aguida B, Chabi NW, Acapko-Ezin J, Sossah-Hiffo J, Agossou VK, et al. Diversity of high risk human papilloma viruses in women treated with antiretroviral and in healthy controls and discordance with cervical dysplasia in the South of Benin. Infect Agents Cancer. 2016;11:1-9.

98. Jedy-Agba EE, Dareng EO, Adebamowo SN, Odutola M, Oga EA, Igbinoba F, et al. The burden of HPV associated cancers in two regions in Nigeria 20122014. Cancer Epidemiology. 2016;45:91-7.

99. Mbulaiteye SM, Katabira ET, Wabinga H, et al. Spectrum of cancers among HIV-infected persons in Africa: the Uganda AIDS-Cancer Registry Match Study. Int J Cancer. 2006;118:985-90.

100. Holmes RS, Hawes SE, Toure' P, et al. HIV infection as a risk factor for cervical cancer and cervical intraepithelial neoplasia in Senegal. Cancer Epidemiol Biomarkers Prev. 2009;18:2442-6.

101. Denny L, Boa R, Williamson A, et al. Human papillomavirus infection and cervical disease in human immunodeficiency virus infected women. Obstel Gynaecol. 2008;111:1380-7.

102. Sahasrabuddhe $\mathrm{V}$, Mwanahamuntu MH, Vermund $\mathrm{SH}$, et al. Prevalence and distribution of HPV genotypes among HIV-infected women in Zambia. Br J Canc. 2007:96:1480-3.

103. Firnhaber C, Zungu K, Levin S, et al. Diverse and high prevalence of human papillomavirus associated with a significant high rate of cervical dysplasia in human immunodeficiency virus infected women in Johannesburg. South Africa ACTA Cytological. 2009;53:10-7.

104. Sun XW, Kuhn L, Ellerbrock TV, Chiasson MA, Bush TJ, Wright TC Jr. Human papillomavirus infection in women infected with the human immunodeficiency virus. N Engl J Med. 1997;337:1343-9.

105. Minkoff H, Feldman J, DeHovitz J, Landesman S, Burk R. A longitudinal study of human papillomavirus carriage in human immunodeficiency virus infected and human immunodeficiency virus-uninfected women. Am J Obstet Gynecol. 1998;178:982-6.

106. Silverberg MJ, Ahdieh L, Munoz A, Anastos K, Burk RD, Cu-Uvin S, et al. The impact of HIV infection and immunodeficiency on human papillomavirus type 6 or 11 infection and on genital warts. Sex Transm Dis. 2002;29:427-35.

107. Chaturvedi AK, Dumestre J, Gaffga AM, Mire KM, Clark RA, Braly PS, et al. Prevalence of human papillomavirus genotypes in women from three clinical settings. J Med Virol. 2005;75:105-13.

108. Strickler HD, Burk RD, Fazzari M, Anastos K, Minkoff H, Massad LS, et al. Natural history and possible reactivation of human papillomavirus in human immunodeficiency virus-positive women. J Natl Cancer Inst. 2005;97:577-86.

109. Olaitan A, Mocroft A, McCarthy K, Phillips A, ReidW JM. Cervical abnormality and sexually transmitted disease screening in human immunodeficiency virus-positive women. Obstet Gynecol. 1997;89:71-5.

110. Maiman M, Fruchter RG, Sedlis A, Feldman J, Chen P, Burk RD, et al. Prevalence, risk factors, and accuracy of cytologic screening for cervical intraepithelial neoplasia in women with the human immunodeficiency virus. Gynecol Oncol. 1998;68:233-9.

111. Delmas MC, Larsen C, van Benthem B, Hamers FF, Bergeron C, Poveda JD, et al. Cervical squamous intraepithelial lesions in HIV-infected women: prevalence, incidence and regression. European Study Group on Natural History of HIV Infection in Women. AIDS. 2000;14:1775-84.

112. Ahdieh L, Munoz A, Vlahov D, Trimble CL, Timpson LA, Shah K. Cervical neoplasia and repeated positivity of human papillomavirus infection in human immunodeficiency virus-seropositive and -seronegative women. Am J Epidemiol. 2000;151:1148-57.

113. Gonc alves MA, Massad E, Burattini MN, Villa LL. Relationship between human papillomavirus (HPV) genotyping and genital neoplasia in HIVpositive patients of Santos City, Sao Paulo, Brazil. Int J STD AIDS. 1999;10: 803-7. 
114. Palefsky JM, Minkoff H, Kalish LA, Levine A, Sacks HS, Garcia P, et al. Cervicovaginal human papillomavirus infection in human immunodeficiency virus-1 (HIV)-positive and high-risk HIV-negative women. J Natl Cancer Inst. 1999:91:226-36.

115. Ellerbrock TV, Chiasson MA, Bush TJ, Sun XW, Sawo D, Brudney K, et al. Incidence of cervical squamous intraepithelial lesions in HIV-infected women. J Am Med Assoc. 2000;283:1031-7.

\section{Publisher's Note}

Springer Nature remains neutral with regard to jurisdictional claims in published maps and institutional affiliations.

Ready to submit your research? Choose BMC and benefit from:

- fast, convenient online submission

- thorough peer review by experienced researchers in your field

- rapid publication on acceptance

- support for research data, including large and complex data types

- gold Open Access which fosters wider collaboration and increased citations

- maximum visibility for your research: over $100 \mathrm{M}$ website views per year

At $B M C$, research is always in progress.

Learn more biomedcentral.com/submissions 